Dowse, J. L. A. (1961): Meckel's Diverticulum, Brit. J. Surg., 48, 392.

Fontaine, R. and BaUER, R. (1933): Aiguille arretee dans une Diverticule de Meckel, Rev. Chir. (Paris), 52, 71 .

Gillette, W. R. and Zoltowski, P. E. (1957): Perforation of Meckel's Diverticulum by a Foreign Body, Amer. J. Surg., 94, 666.

HAGler, F. and STEWART, J. W. (1920): Acute Perforation of Meckel's Diverticulum by a Foreign Body (Fishbone), J. Amer. med. Ass., 74, 1377.

HENRICHSEN, A. (1921): Ueber einen Fäll von Fremkörperdivertikulitis des Meckel'schen Divertikels, Münch. med. Wschr., 68, 1423.

Hiller, R. I. and BERNHARD, L. A. (1933): Gangrenous Meckel's Diverticulum Perforated by a Tomato Peel., J. Amer. med. Ass., 101, 364.

JoHN, E. L. (1955): Perforation of Meckel's Diverticulum by a Pin, Brit. J. Surg., 43, 216.

KER, H. (1962): A Muckle of Meckel's, Lancet, i, 617.

Komarov, I. A. (1959): Perforation of Meckel's Diverticulum, Vestn. Khir., 83, 88.

LINDQUIST, S. (1926): Perforation eines Meckel'schen Divertikels, von einem Fremdkörper Bedingt, Zbl. Chir., 53, 1756.

Longo, T., and Broggi, L. (1954): Di una Singolare Complicanza di un Diverticolo di Meckel, Boll. Soc. med. chir. Varese., 9, 256.

MacFarlane, D. A. (1948): Foreign Body Perforations in Meckel's Diverticulum, Brit. J. Surg., 35, 421.

Mastrosimone, C. (1951): Perforazione del Diverticolo di Meckel ed Ascaridiasi, Arch. Att. Soc. It. Chir., 2, 359.

MeCKel, J. F. (1812): Handbuch der Pathologischen Anatomie, Vol. 1, p. 553, (Leipzig).

Persson, von T., (1939): Meckel'sches Divertikel, durch einen Fremkörper Perforiert, Acta chir. scand., 82, 530 .

Peterson, E. W. (1937): Commenting on Donovan (loc. cit.), Ann. Surg., 106, 954.
Piquand, G. and Grenet, H. (1900): Perforation d'un Diverticule Ileal par une Arete de Poisson, Bull. Soc. Anat. Paris, p. 390.

Principe, L. (1960): Perforazione da Corpo Estraneo di Diverticolo di Meckel Fibroangiomatoso, Riv. Pat. Clin., 15, 503.

Rawlinson, J. K. M. (1956): Fishbone Perforation of Meckel's Diverticulum, Brit. J. Surg., 43, 555.

Reinalda, R. (1958): A Case of Meckel's Diverticulum Perforated by a Fishbone, Geneesk. Gids., 36, 383.

RoEsSEL, C. W. (1962): Perforation of Meckel's Diverticulum by a Foreign Body; case report and review of the literature, Ann. Surg., 156, 972.

Rossman, J. I. (1943): Fishbone Perforation of Meckel's Diverticulum, Canad. med. Ass. J., 49, 48.

RUMORE, A. (1958): Perforation of Meckel's Diverticulum by Grape Seeds, Med. J. Aust., 45, 110.

RuYsCH, F. (1701): Thesaurus Anatomicus, Vol. 7, Fig. 383.

SCHWENK, C., and Pollnow, M. (1912): Fremdkörper im Meckel'schen Divertikel unter den Erscheinungen der Appendicitis, Berl. klin. Wschr., 49, 2228.

SEIBERT, F. M. (1950): Seltene Erkrankingsformd des Meckel'schen Divertikel. Fremdkörperperforation ohne Begleitdiverticulitis, Artzl. Wschr, 550, 1023.

Tamraz, J. M. (1940): Case of Acute Gangrenous Diverticulitis (Meckel's) with Perforation due to a Fishbone, Milit. Surg., 87, 328.

WALKLING, cited by Webb (q.v.).

WARD-MCQuAID, J. N. (1950): Perforated Meckel's Diverticulum by Tomato Skin, Lancet, i, 349.

WEBB, R. C. (1933): Meckel's Diverticulum Perforated by a Fishbone, Ann. Surg., 98, 159.

Weinstein, V. A. (1942): Fishbone Perforation of Meckel's Diverticulum, J. Mt. Sinai Hosp., 9, 29.

Whelan, P. J. (1951): Fishbone Perforation of Meckel's Diverticulum, Canad. med. Ass. J., 64, 67.

Wilcox, A. E. (1932): Case Report, Minn. Med., 15, 558.

Williams, R. V. (1940): Perforation of Meckel's Diverticulum by a Fishbone, Minn. Med., 23, 44.

\title{
SPONTANEOUS NECROSIS OF THE GALL BLADDER
}

\author{
J. E. Mitchell, M.B., B.Ch. (Wales), F.R.C.S. (Eng.). \\ Late Senior Surgical Registrar, The Gordon Hospital, Vauxhall Bridge Road, London, S.W.1.
}

\begin{abstract}
RUPTURE of the gall bladder is not an uncommon phenomenon usually associated with gangrene following acute calculous cholecystitis. Cases have been reported following non-calculous cholecystitis (Maingot, 1957) and there are other isolated cases of rarer causes.
\end{abstract}

\section{Case Report}

A male, aged 58, presented with a history of bleeding per rectum for six months. Routine sigmoidoscopy showed a carcinoma $11 \mathrm{~cm}$. from the anus, confirmed by histological examination.

On 7 th January, 1964 laparotomy showed a mobile carcinoma of the rectum with no obvious metastases. The gall bladder and other abdominal viscera were normal. A routine abdomino-perineal excision of the rectum was performed and his immediate recovery was satisfactory. On the ninth post-operative day pus was drained from his wound which had become inflamed and three days later he developed general peritonitis. Laparotomy showed a biliary peritonitis, there being about a pint of free bile in the abdomen. A large swelling was found in the right upper abdomen consisting of omentum wrapped round the gall bladder. On freeing the omentum, the gall bladder was found to be deeply bile stained and black at the fundus and there was a little bile 
staining of the omentum and under surface of the liver. The common bile duct appeared normal. Cholecystectomy was performed. By the following day he had developed a purulent bronchitis and sputum retention which necessitated tracheostomy and his further course was complicated by dehiscence of the abdominal wounds and a right-sided pleural effusion. In the sixth post-operative week, while gradually improving, he developed a right-sided hemiplegia, became stuporous and died.

Necropsy revealed thrombosis of the right middle cerebral artery with softening of the appropriate area of brain, bilateral pleural effusions and pulmonary œdema. He had acute endocarditis with multiple septic infarcts of kidney and adrenal. There were multiple abscesses in the abdominal cavity; but the region of the gall bladder bed was normal and the liver also appeared normal.

Histology of the gall bladder: "the inner wall of the gall bladder is necrotic and cellular detail is not recognisable. The serosa shows hyperæmia, proliferation of connective tissue and small blood vessels and an infiltration by polymorphs and some lymphocytes and plasma cells. There is yellow bile staining of these tissues."

\section{Discussion}

The complication which caused this patient's death was necrosis of the gall bladder. The ætiology of this condition is obscure. The histological appearances do not exclude infarction of the gall bladder wall but why this should happen is not certain. Thrombosis of the cystic artery should not in itself lead to gall bladder infarction as there is a rich blood supply from the peritoneum and liver bed, although it is possible that it could cause a localised patch of gangrene (Maingot, 1957). The mechansim of the bile leakage is also obscure as the gall bladder wall was apparently intact and the gall bladder tense. It is possible that with destruction of the mucosa the gall bladder becomes permeable to bile. Cope (1925) quoted a case of spontaneous biliary peritonitis with a tense gall bladder and ${ }_{c}$ postulated that a minute leak followed by partial $\Rightarrow$ collapse of the gall bladder with subsequents sealing of the leak occurred. Ellis (1960) quotedo a case of Small's (1954) in which spontaneous biliary peritonitis was found to be due to $a \frac{\bar{m}}{\bar{c}}$ minute hole in the gall bladder plugged with $\vec{\sigma}^{-}$ fibrin. He also described two cases of spontaneous $\varrho$ perforation of the gall bladder; one in a case of thrombocytopenic purpura with hæmorrhagic destruction of the gall bladder wall and another. case of a small perforation with localised $\overrightarrow{\vec{\omega}}$ endarteritis in a near-by vessel.

The case described resembles, in certain res-pects, that of Small's (1954) except in its severity and total involvement of the gall bladder wall. This rare condition has not been previously. described in a gall bladder which was known to be macroscopically normal beforehand.

\section{Summary}

A case of spontaneous necrosis of the pre-음 viously normal gall bladder, complicating-

excision of the rectum, is described.
I am grateful to $\mathrm{Mr}$. R. W. Raven under whose $\frac{\mathbb{D}}{\mathrm{O}}$ care this patient was, for permission to publish the case history.

\section{REFERENCES}

COPE, Z. (1925): Extravasation of Bile, Brit. J. Surg\%, G 13, 120

Ellis, H., and Cronin, K. (1960): Bile Peritonitis, Brit. J. Surg., 43, 166.

MAINGOT, R. (1957): The Management of Abdominal Operations, p. 827, London: H. K. Lewis.

Small, W. P. (1954): A Case of Biliary Peritonitis, $\stackrel{\circ}{\mathbb{Q}}$ Brit. J. Surg., 41, 552. 